\title{
Identification of tuna species Thunnus albacares and Katsuwonus pelamis in canned products by real-time PCR method
}

\author{
Pavel Krcmar ${ }^{1}$, Zora Piskata ${ }^{1}$, Eliska Servusova ${ }^{1,2}$ \\ ${ }^{1}$ Veterinary Research Institute Brno, Brno, Czech Republic \\ ${ }^{2}$ University of Veterinary and Pharmaceutical Sciences Brno, Faculty of Veterinary Hygiene and Ecology, \\ Department of Meat Hygiene and Technology, Brno, Czech Republic
}

Received April 1, 2019

Accepted June 13, 2019

\begin{abstract}
Tuna species are a popular food among consumers. They are mostly sold as heat-processed canned products on the market. Different quality and price of tuna species can lead the producer to the adulteration of food products. The main difficulties in developing a method for species identification in these fish is the high similarity of DNA sequences among close relative fish species. All complete mitochondrial DNA sequences of skipjack tuna (Katsuwonus pelamis) and yellowfin tuna (Thunnus albacares) were compared to all other mitochondrial DNA sequences of tuna fish deposited in the GenBank. The most variable regions within species were determined and primers and probes were designed in this region for the species-specific DNA amplification of skipjack tuna and yellowfin tuna. Moreover, to check the content of amplifiable DNA of fish (namely tuna) in the sample, primers and a probe of mitochondrial $12 S r R N A$ gene in the region of conservative sequence were designed. Real time PCR methods were verified by investigating 51 samples of canned tuna with the declared content of tuna species from the market; the species was confirmed in all tested samples. This method was designed to be suitable for the determination of DNA sequences especially in highly heat treated products.
\end{abstract}

Yellowfin tuna, skipjack tuna, food authentication, species detection

Tuna is one of the most popular fish species on the food market. Most often they are offered in the form of canned products. Among the species used in cans, skipjack (Katsuwonus pelamis) and yellowfin tuna (Thunnus albacares) dominate. Furthermore, the market offers raw or frozen fillets, most often yellowfin tuna. The different quality and price of other tuna species can lead producers to confusing the species. The Council Regulation (EEC) No. 1536/92 laying down common marketing standards for preserved tuna and bonito states specific rules for the tuna marketing. The species belonging to tuna and bonito are listed in the Annex of this Regulation. Tuna includes the genus Thunnus (T. thynnus, T. albacares, T. alalunga, T. obesus and others) and the species Euthynnus (Katsuwonus) pelamis. Sarda sp., Euthynnus sp. (except Euthynnus pelamis) and Auxis sp. are grouped among bonitos. One of the Regulation's paragraphs says that different species may not be mixed in the same container. According to DNA analysis of tuna species, several works have described different techniques based on multiplex PCR (Bottero et al. 2007; Michelini et al. 2007; Lin and Hwang 2008), real-time PCR (Lopez and Pardo 2005, Dalmasso et al. 2007, Chuang et al. 2012; Bojolly et al. 2017) and others. To differentiate individual fish species based on DNA sequences, an increasingly widespread DNA barcoding method can be used for raw, i.e. non-heat treated samples. This method is based on the sequencing of a 655 nucleotide long stretch of mitochondrial DNA encoding a portion of the cytochrome oxidase gene, and subsequent comparison of the obtained sequence with DNA Sequence Database (Handy et al. 2011). DNA is degraded during the manufacturing process of heat treated products, so a methodology that uses shorter DNA sequences for

Address for correspondence:

Pavel Krcmar

Veterinary Research Institute Brno

Hudcova 70, 62100 Brno, Czech Republic
Phone: +420 533331913

E-mail: krcmarp@post.cz; zorah@email.cz

http://actavet.vfu.cz/ 
species resolution is needed. This requirement is met by the real-time PCR method, which allows the determination of DNA sequences of 80 to 200 nucleotides. The main difficulty for developing a method for distinguishing these fish species based on the analysis of species-specific DNA sequences is the high identity of DNA sequences among related fish species. The complete nuclear DNA sequence is described only in Thunnus orientalis (Nakamura et al. 2013). The main focus was, therefore, put on mitochondrial DNA, as it has been described in all the species studied in several individuals of each species (Manchado et al. 2004; Catanase et al. 2008; Guo et al. 2016; Chen et al. 2016; Li et al. 2016a,b,c,d; Marquez et al. 2016; Pang et al. 2016a,b; Yang et al. 2016).

The aim of this work was to develop a method for the determination of skipjack and yellowfin tuna in highly heat treated products based on amplification of species-specific mitochondrial DNA sequences by real-time PCR.

\section{Materials and Methods}

\section{Sample preparation}

The muscles of yellowfin tuna (Thunnus albacares), skipjack tuna (Katsuwonus pelamis) and other tuna species were obtained from European Union markets. Their species identification was carried out according to their morphological features or were subjected to sequencing of the cyt $b$ gene to confirm the species declaration. For the evaluation of the developed real-time PCR methods, 51 food products (canned products and pate) containing tuna fish were analysed. These commercial products were obtained on the local markets in the Czech Republic.

DNA isolation

DNA was isolated from 100-200 mg fish muscle using a commercial kit, DNeasy mericon Food Kit (Qiagen $\mathrm{GmbH}$, Hilden, Germany) according to the manufacturer's instructions. DNA was isolated from all samples in duplicate.

Table 1. Published complete mitochondrial DNA sequences of tuna and bonito (GenBank; https://www.ncbi.nlm.nih.gov/nuccore).

\begin{tabular}{ll}
\hline Tuna/bonito species & Complete mitochondrial DNA (Sequence ID) \\
\hline Katsuwonus pelamis & KM605252, JN086155, GU256527, AB101290 \\
Thunnus albacares & KP259550, KT724724, KM588080, JN086153, GU256528 \\
Thunnus alalunga & JN086151, KP259549, GU256526, AB101291 \\
Thunnus tonggol & HQ425780, JN086154 \\
Thunnus thynnus & JN086149, GU256522, KF906720, AY302574, AB097669, AP006034 \\
Thunnus atlanticus & KU955344, KM405517, KU955343 \\
Thunnus orientalis & KF906721, GU256524, AB185022 \\
Thunnus obesus & JN086152, GU256525 \\
Thunnus maccoyii & JN086150, GU256523, KF925362 \\
Auxis rochei & AB103468, KP259548, KM651784, AB105165, AB103467 \\
Auxis thazard & KP259551, AB105447 \\
Euthynnus affinis & AP012946, KM651783 \\
Euthynnus alletteratus & AB099716 \\
Sarda orientalis & AP012949 \\
\hline
\end{tabular}

Probes and primers design

The primers and probes for real-time amplification and species specific determination were newly designed. Using Blast (https://blast.ncbi.nlm.nih.gov/Blast.cgi) all sequences of complete mitochondrial skipjack tuna DNA (GenBank: KM605252, JN086155, GU256527, AB101290) and yellowfin tuna (GenBank: KP259550, KM588080, KT724724, GU256528, JN086153) were compared with all other mitochondrial DNA sequences of tuna (Table 1) contained in the GenBank (https://www.ncbi.nlm.nih.gov/nuccore). Areas that were variable within the same species were identified and excluded from further assessment. Furthermore, 


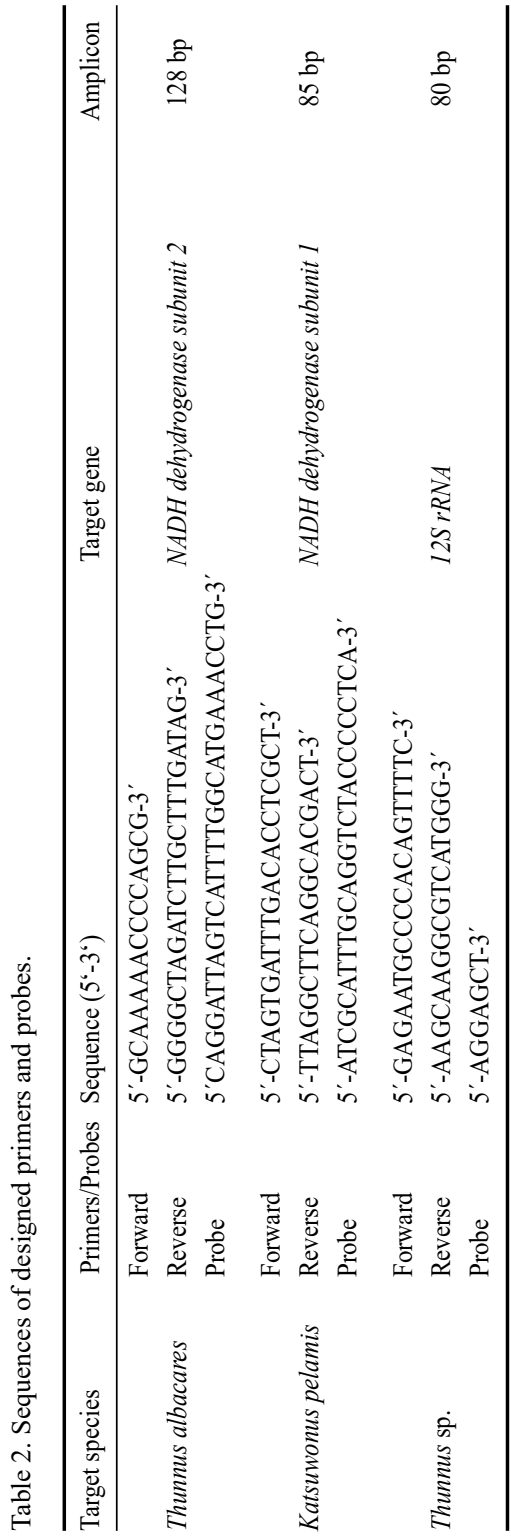

the most variable interspecies regions were determined, and primers and probes for species-specific amplification of skipjack tuna and yellowfin tuna were designed in this section. The primers and probes were designed and synthetized by TIB MolBiol (Berlin, Germany). The probes were labelled on the 5 '-end with the fluorescent reporter dye 6-carboxyfluorescein (FAM) and on the 3'-end were labelled with a quencher BBQ. The sequences of primers and probes are listed in Table 2. Additionally, primers and probe were designed to determine the presence of amplifiable fish (especially tuna) DNA in the sample to determine the part of the $12 S$ rRNA mitochondrial gene sequence in the fish-conserved region. For this system, a Locked Nucleic Acid (LNA) probe (Probe no. 17, Roche Diagnostic GmbH, Mannheim, Germany) was used. The probe was designed via Universal ProbeLibrary Assay Design Center (www.lifescience.roche.com/en_cz/brands/universal-probelibrary.html).

Real-time PCR conditions

Amplification was performed with the LightCycler 1.5 instrument (Roche Diagnostics International Ltd., Rotkreuz, Switzerland) with the following programme: initial denaturation $\left(50{ }^{\circ} \mathrm{C}\right.$ for $2 \mathrm{~min}$ and $95{ }^{\circ} \mathrm{C}$ for $15 \mathrm{~min}$ ), amplification $\left(40\right.$ cycles of $95^{\circ} \mathrm{C}$ for $15 \mathrm{~s}$, and $60^{\circ} \mathrm{C}$ for $60 \mathrm{~s})$. The reaction mixture $(10 \mu \mathrm{l})$ contained $5 \mu \mathrm{l}$ QuantiTect Probe PCR Kit (Qiagen GmbH, Hilden, Germany), $2 \mu 1$ of the isolated DNA sample, $1 \mu \mathrm{l}$ of primer and probe solution $(5 \mu \mathrm{M}$ of each primer and $1 \mu \mathrm{M}$ ) probes), and $2 \mu 1 \mathrm{H}_{2} \mathrm{O}$.

Method specificity

Besides the testing of specificity in silico the species specificity of the proposed primers and probes was also verified on DNA samples of the following tuna and bonito species: bullet tuna (Auxis rochei), frigate tuna (Auxis thazard), yellowfin tuna (Thunnus albacares), Atlantic bluefin tuna (Thunnus thynnus), albacore tuna (Thunnus alalunga), bigeye tuna (Thunnus obesus), southern bluefin tuna (Thunnus maccoyii), skipjack tuna (Katsuwonus pelamis), black skipjack or mackerel tuna (Euthynnus affinis), Atlantic little tuna (Euthynnus alletteratus), Atlantic bonito (Sarda sarda).

\section{Detection limit}

The detection limit was assessed by determination of the DNA concentration isolated from randomly selected three investigated cans of Thunnus albacares and three cans of Katsuwonus pelamis after dilution corresponding to $1 \%$ of the original content. DNA concentration was determined by fluorescence method using a Qubit dsDNA HS Assay Kit (Thermo Fisher Scientific, Waltham, MA, USA) and quantified by a Qubit fluorometer (Thermo Fisher Scientific, MA, USA).

\section{Real-time PCR efficiency test}

To evaluate the efficiency of designed real-time PCR systems for Thunnus albacares, Katsuwonus pelamis and Thunnus sp., three samples for each canned tuna were tested. For each individual, DNA concentrations were adjusted by serial dilution in water to $10 \%, 1 \%$, and $0.1 \%$. The efficiency was estimated by plotting $\mathrm{Cp}$ values against the logarithm of the DNA concentration, with the efficiency $=\left[10^{(-1 / \text { slope })}-1\right] \times 100 \%$.

\section{Method validation on real samples}

Real-time PCR methods for the determination of two tuna species were verified on 51 canned products with a declared tuna content purchased on the market. The food products contained tuna muscle in own juice, tuna muscle in olive oil, sunflower oil, soybean oil, tuna in brine, tuna in tomato sauce or tuna cream. 


\section{Results}

All sequences of complete mitochondrial skipjack tuna DNA and yellowfin tuna were compared with all other mitochondrial DNA sequences of tuna contained in the GenBank and species-specific primers and probes for yellowfin tuna (128 bp long product) and skipjack ( 85 bp long product) detection were designed. For confirmation of the presence of fish DNA (especially tuna fish) in the sample, $12 \mathrm{~S} r R N A$ mitochondrial gene sequence (80 bp long product) was detected. The locked nucleic acid (LNA) probe is suitable for its short length (7 oligonucleotides), the possibility of designing a short amplicon (up to 100 base pairs), and easy commercial availability. Besides in silico comparison of complete mitochondrial DNA sequences of tuna and bonito deposited in the GenBank, the species specificity of the proposed primers and probes was also verified on DNA samples of the following tuna species: Auxis rochei, Auxis thazard, Thunnus albacares, Thunnus thynnus, Thunnus alalunga, Thunnus obesus, Thunnus maccoyii, Katsuwonus pelamis, Euthynnus affinis, Euthynnus alletteratus, Sarda sarda and no cross reaction was found (data not shown).

The detection limit for heat treated samples isolated under given conditions was established at $3.2 \mathrm{ng}$ DNA/ml sample for Katsuwonus pelamis and $2.5 \mathrm{ng}$ DNA/ml sample for determination of Thunnus albacares.

For validation of the detection systems, the linearity and efficiency were tested. The linearity was tested by plotting the $\mathrm{Cp}$ values $(\mathrm{Cp}$ - Crossing point, the point at which the fluorescence of the sample rises above the background fluorescence) versus the logarithmic of the DNA concentration (Plate VI, Figs 1-2, Plate VII, Fig 3). The efficiencies for all the systems ranged from $92.31 \%$ to $107.01 \%$.

The suitability of the developed real-time PCR systems for canned tuna authentication was tested on 51 commercial products with a declaration of tuna species on packaging (28 were labelled as skipjack tuna, 23 as yellowfin tuna) that were purchased on the market of the Czech Republic. Samples with a Cp lower than 32.0 were considered positive. The lower the $\mathrm{Cp}$, the more DNA the sample contains. Fish (tuna) DNA was detected in all samples. The cans labelled as skipjack tuna were confirmed when using primers/probes specific for skipjack tuna. Skipjack tuna was not detected in any commercial can labelled as yellowfin tuna. Similarly, in cans labelled as yellowfin tuna, the DNA of yellowfin tuna was confirmed using primers/probe for yellowfin tuna detection.

\section{Discussion}

Tuna species identification according to their morphologic features is impossible in highly processed food products. DNA-based analytical methods offer a solution, although the DNA is degraded into smaller fragments during the canning process, but these fragments are still detectable. Ram et al. (1996) claimed that the canning process degrades DNA to fewer than $123 \mathrm{bp}$ in length. Moreover, DNA is largely independent of tissue source, age, or sample damage (Bossier 1999; Lockley and Bardsley 2000). Concerning canned tuna, most studies showed a preference for mitochondrial DNA in relation to nuclear DNA because of its relative abundance and circular structure, which provides higher resistance to thermal degradation (Bossier 1999). A close phylogenetic relationship exists among Thunnus species due to high homology in their DNA sequences. Consequently, lower interspecific (mostly single nucleotide polymorphism) but relatively high intraspecific variability among particular tuna species makes it difficult to design a specific approach for their identification. Several methodological systems based on the detection of species-specific DNA have been developed for species identification of tuna in both raw and preserved products [PCR-RFLP (Quinteiro et al. 1998, Pardo and Perez-Villareal 2004, Lin et al. 2005, Lin and Hwang 2007), PCR-SSCp (Colombo 
et al. 2005), PCR-ELISA (Santaclara et al. 2015), multiplex PCR (Bottero et al. 2007; Michelini et al. 2007; Lin and Hwang 2008) or real-time PCR (Lopez and Pardo 2005, Dalmasso et al. 2007, Chuang et al. 2012; Bojolly et al. 2017)]. DNA barcoding involves PCR analysis followed by sequencing to identify species based on DNA polymorphisms (Botti and Giuffra 2010). However, its usefulness may be limited in the case of species identification of fish in products containing a mixture of more fish species or in highly processed products where DNA could be degraded into smaller fragments that are difficult to detect. In this study, the developed real-time PCR systems enable us to detect two tuna species and to eliminate false negative results, simultaneously. In general, the potential misrepresentation of declared and confirmed specimen can be regarded as a manufacturing mistake rather than a deliberate deception of the consumer by a less valuable product (i.e. the use of lower quality meat of another less valuable species).

Due to the high degree of heat treatment used in canned products which causes DNA degradation, it is relatively difficult to use absolute quantification for DNA determination. The detection limit was assessed by determination of the concentration of DNA isolated from three randomly selected cans after dilution corresponding to $1 \%$ of the original content. This limit has been set at $1 \%$, following the request of the tuna canning industry, which allows discrimination between voluntary substitutions from involuntary substitutions (Bojolly et al. 2017).

In conclusion, this developed real-time PCR method has been designed to maximize species-specific assays using all current knowledge of tuna fish DNA sequences. The mitochondrial sequences that are most variable among related tuna species have been used to design primers and probes and are not variable within the species. The use of DNA sequences with these properties is a major difference from the methods outlined above. The method was further designed to be suitable for the determination of DNA sequences in highly heat treated products.

\section{Acknowledgements}

This work was supported by the Ministry of Agriculture of the Czech Republic (grants no. QJ1530272 and RO0518). The authors would like to thank Ludmila Faldikova (Veterinary Research Institute Brno, Czech Republic) for grammatical correction of the manuscript.

\section{References}

Bojolly D, Doyen P, Le Fur B, Christaki U, Verrez-Bagnis V, Grard T 2017: Development of a qPCR method for the identification and quantification of two closely related tuna species, bigeye tuna (Thunnus obesus) and yellowfin tuna (Thunnus albacares), in canned tuna. J Agric Food Chem 65: 913-920

Bossier P 1999: Authentication of seafood products by DNA patterns. J Food Sci 64: 189-193

Bottero MT, Dalmasso A, Cappelletti M, Secchi C, Civera T 2007: Differentiation of five tuna species by a multiplex primer-extension assay. J Biotechnol 129: 575-580

Botti S, Giuffra E 2010: Oligonucleotide indexing of DNA barcodes: identification of tuna and other scombrid species in food products. BMC Biotechnol 10: 60

Catanese G, Infante C, Manchado M 2008: Complete mitochondrial DNA sequences of the frigate tuna Auxis thazard and the bullet tuna Auxis rochei. DNA Sequence 19: 159-166

Chen C, Li YL, Yu H, Peng SM, Sun SG, Wang L, Meng XJ, Huang Y, Komg XD 2016: The complete mitochondrial genome of the juvenile Pacific bluefin tuna Thunnus orientalis (Perciformes, Scombridae). Mitochondrial DNA 27: 71-72

Chuang P, Chen M, Shiao J 2012: Identification of tuna species by a real-time polymerase chain reaction technique. Food Chem 133: 1055-1061

Colombo F, Mangiagalli G, Renon P 2005: Identification of tuna species by computer-assisted and cluster analysis of PCR-SSCp electrophoretic patterns. Food Control 16: 51-53

Council Regulation (EC) No 1536/92 of the European Parliament and of the Council of 9 June 1992 laying down common marketing standards for preserved tuna and bonito. Official Journal L163: 1-4

Dalmasso A, Fontanella E, Piatti P, Civera T, Secchi C, Bottero MZ 2007: Identification of four tuna species by means of real-time PCR and melting curve analysis. Vet Res Commun 31: 355-357 
Guo L, Li MM, Zhang H, Yang S, Chen XH, Meng ZN, Lin HR 2016: Next-generation sequencing of the yellowfin tuna mitochondrial genome reveals novel phylogenetic relationships within the genus Thunnus. Mitochondrial DNA 27: 2089-2090

Handy SM, Deeds JR, Ivanova NV, Hebert PDN, Hanner RH, Ormos A, Weigt, LA, Moore MM, Yancy HF 2011: A single-laboratory validated method for the generation of DNA barcodes for the identification of fish for regulatory compliance. J AOAC Int 94: 201-210

Li MM, Guo L, Zhang H, Yang S, Chen XH, Meng ZN, Lin HR 2016a: Complete mitochondrial genome of the kawakawa tuna Euthynnus affinis. Mitochondrial DNA 27: 2147-2148

Li MM, Guo L, Zhang H, Yang S, Chen XH, Lin HR, Meng ZN 2016b: Mitochondrial genome of the bullet tuna Auxis rochei from Indo-West Pacific collection provides novel genetic information about two subspecies. Mitochondrial DNA 27: 3071-3072

Li YL, Chen C, Yu H, Peng SM, Sun SG, Wang L, Meng XJ, Huang Y, Kong XD 2016c: The complete mitochondrial genome of the juvenile Atlantic bluefin tuna Thunnus thynnus (Perciformes, Scombridae). Mitochondrial DNA 27: 96-97

Li YL, Chen C, Yu H, Peng SM, Sun SG, Wang L, Meng XJ, Huang Y, Kong XD 2016d: The complete mitochondrial genome of the Southern bluefin tuna Thunnus maccoyii. Mitochondrial DNA 27: 3921-3922

Lin WF, Shiau CY, Hwang DF 2005: Identification of four Thunnus tuna species using mitochondrial cytochrome $b$ gene sequence and PCR-RFLP analysis. J Food Drug Anal 13: 382-387

Lin WF, Hwang DF 2007: Application of PCR-RFLP analysis on species identification of canned tuna. Food Control 18: 1050-1057

Lin WF, Hwang DF 2008: A multiplex PCR assay for species identification of raw and cooked bonito. Food Control 19: 879-885

Lockley AK, Bardsley RG 2000: DNA-based methods for food authentication. Trends Food Sci Tech 11: 67-77

Lopez I, Pardo MA 2005: Application of relative quantification TaqMan real-time polymerase chain reaction technology for the identification and quantification of Thunnus alalunga and Thunnus albacares. J Agric Food Chem 53: 4554-4560

Manchado M, Catanese G, Infante C 2004: Complete mitochondrial DNA sequence of the Atlantic bluefin tuna Thunnus thynnus. Fish Sci 70: 68-73

Marquez EJ, Isaza JP, Alzate JF 2016: Mitochondrial genome of the blackfin tuna Thunnus atlanticus Lesson, 1831 (Perciformes, Scrombidae). Mitochondrial DNA 27: 1771-1772

Michelini E, Cevenini L, Mezzanotte L, Simoni P, Baraldini M, De Laude L, Roda A 2007: One-step triplexpolymerase chain reaction assay for the authentication of yellowfin (Thunnus albacares), bigeye (Thunnus obesus) and skipjack (Katsuwonus pelamis) tuna DNA from fresh, frozen and canned tuna samples. J Agric Food Chem 55: 7638-7647

Nakamura Y, Mori K, Saitoh K, Oshima K, Mekuchi M, Sugaya T, Shigenobu Y, Ojima N, Muta S, Fujiwara A, Yasuike M, Oohara I, Hirakawa H, Chovdhury VS, Kobayashi T, Nakajima K, Sano M, Wada T, Tashiro K, Ikeo K, Hattori M, Kuhara S, Gojobori T, Inouye K 2013: Evolutionary changes of multiple visual pigment genes in the complete genome of Pacific bluefin tuna. Proc Natl Acad Sci USA 110: 11061-11066

Pang JH, Cheng QQ, Sun DD, Zhang H, Jin SF 2016a: The sequence and organization of complete mitochondrial genome of the yellowfin tuna, Thunnus albacares (Bonnaterre, 1788). Mitochondrial DNA 27: 3111-3112

Pang JH, Cheng QQ, Sun DD, Zhang H, Jin SF 2016b: The complete mitochondrial genome sequence of Thunnus alalunga (Bonnaterre, 1788). Mitochondrial DNA 27: 4189-4190

Pardo MA, Pérez-Villareal B 2004: Identification of commercial canned tuna species by restriction site analysis of mitochondrial DNA products obtained by nested primer PCR. Food Chem 86: 143-150

Quinteiro J, Sotelo CG, Rehbein H, Pryde SE, Medina I, Perez-Martin RI, Rey-Mendez M, Mackie IM 1998: Use of mtDNA direct polymerase chain reaction (PCR) sequencing and PCR-restriction fragment lenght polymorphism methodologies in species identification of canned tuna. J Agric Food Chem 46: 1662-1669

Ram JL, Ram ML, Baidoun FF 1996: Authentication of canned tuna and bonito by sequence and restriction site analysis of polymerase chain reaction products of mitochondrial DNA. J Agric Food Chem 44: 2460-2467

Santaclara FJ, Velasco S, Pérez-Martín RI, Quinteiro J, Rey-Méndez M, Pardo MA, Jimenez E, Sotelo CG 2015: Development of a multiplex PCR-ELISA method for the genetic authentication of Thunnus species and Katsuwonus pelamis in food products. Food Chem 180: 9-16

Yang S, Li MM, Zhang H, Guo L, Chen XH, Meng ZN, Lin HR 2016: The complete mitochondrial genome of skipjack tuna (Katsuwonus pelamis) determined by HiSeq sequencing. Mitochondrial DNA 27: 3973-3974 
Plate VI

Krcmar P.. et al.: Identifications of tuna ... pp. 323-328

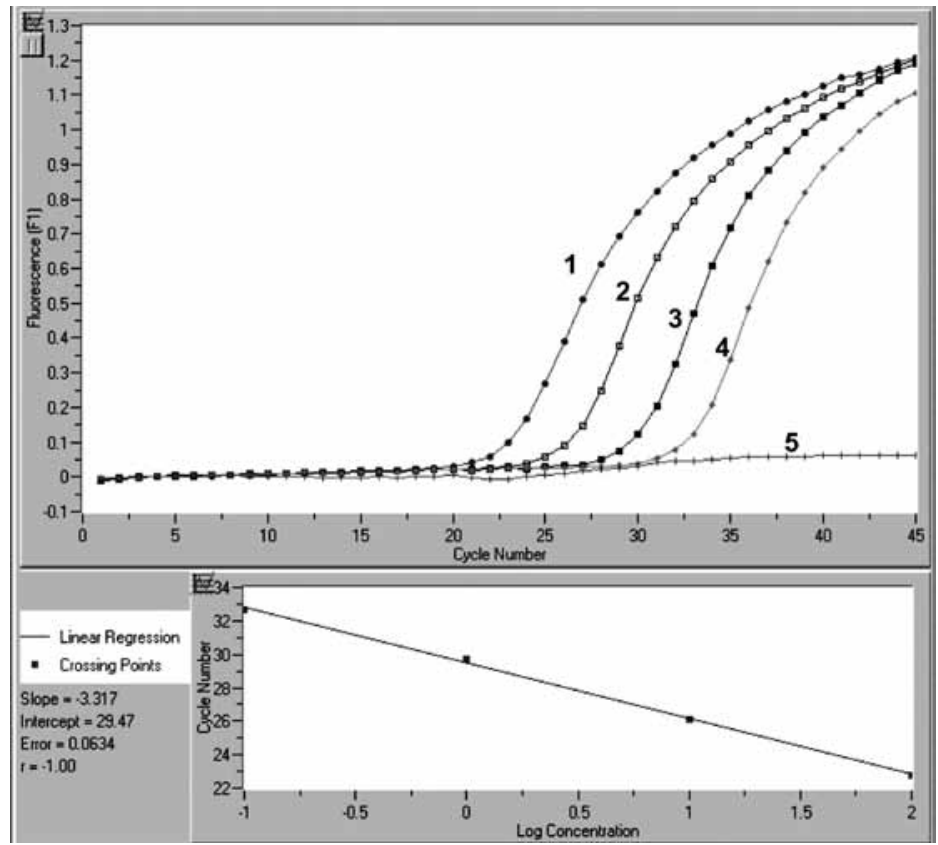

Fig. 1. Calibration curve for amplification of Thunnus albacares DNA Serial of DNA dilution: $100 \%$ (1), $10 \%$ (2), $1 \%$ (3), $0.1 \%$ (4), water (5).

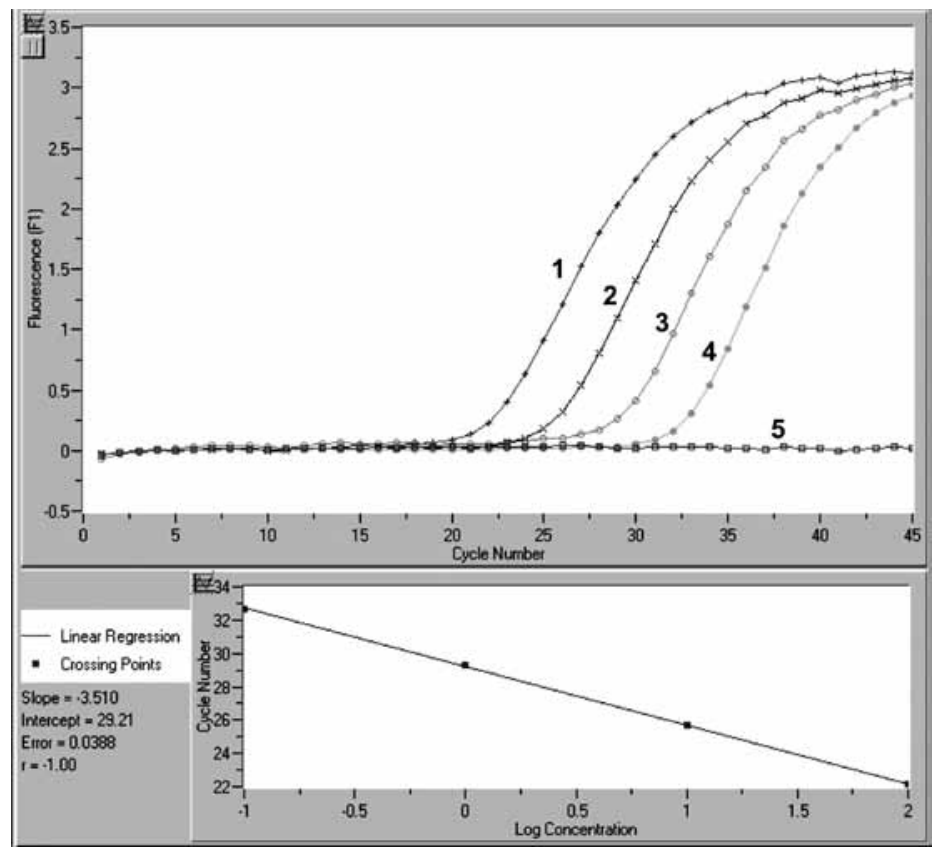

Fig. 2. Calibration curve for amplification of Katsuwonus pelamis DNA

Serial of DNA dilution: $100 \%(1), 10 \%(2), 1 \%(3), 0.1 \%(4)$, water (5). 


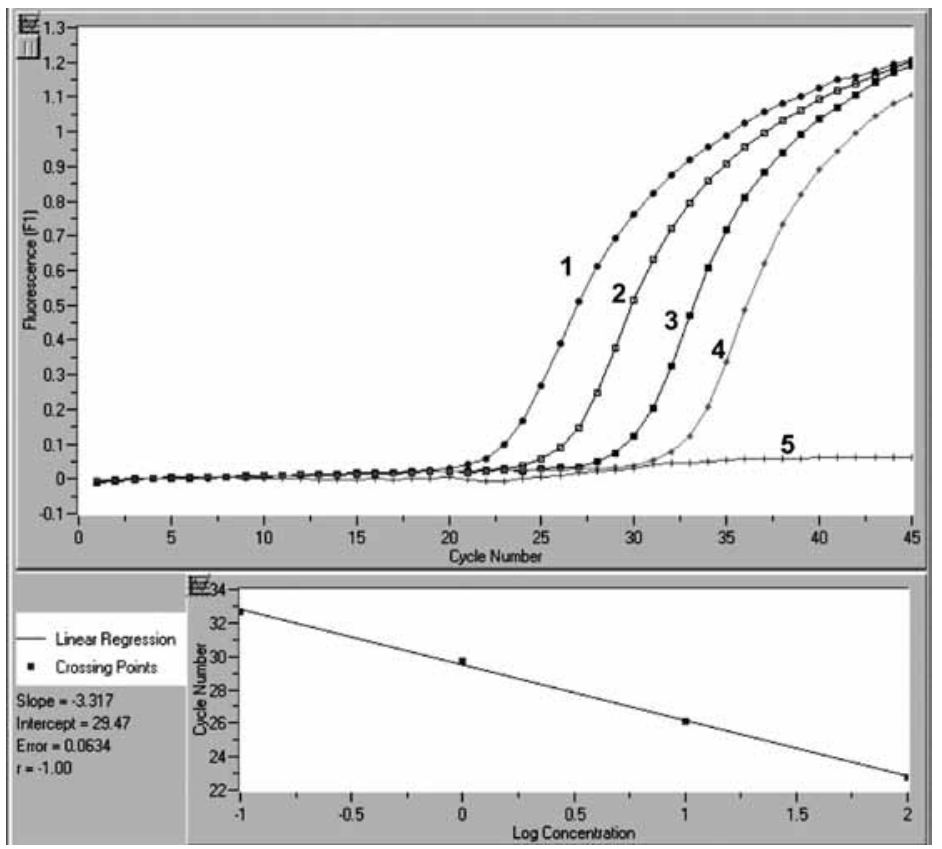

Fig. 3. Calibration curve for amplification of Thunnus sp. DNA

Serial of DNA dilution: $100 \%$ (1), $10 \%$ (2), $1 \%$ (3), $0.1 \%$ (4), water (5). 